\title{
Customized acrylic implants for reconstruction of extensive skull defects: an exception approach for selected patients
}

\section{Implantes de acrílico customizados para a reconstrução de defeitos extensos da calota craniana: uma abordagem de exceção para pacientes selecionados}

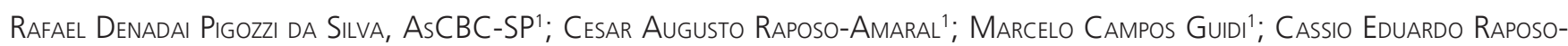
-Amaral'; Celso Luiz Buzzo'1.

\section{A B S T R A C T}

\begin{abstract}
Objective: to present our experience in the surgical treatment of extensive skullcap defects with customized acrylic implants. Methods: we conducted a retrospective analysis of patients with extensive skull defects undergoing acrylic cranioplasties between 2004 and 2013. We carefully selected all patients and classified surgical results based on three scales (craniofacial esthetics, improvement of facial symmetry and need for additional surgery). Results: fifteen patients underwent cranioplasty with intraoperative acrylic implants, whether manually customized (46.67\%) or made with prototyped three-dimensional biomodels (53.33\%). There were two (13.33\%) complications (one infection with implant withdrawal and one seroma). We considered the craniofacial aesthetics excellent (50\%), the degree of improvement of craniofacial symmetry satisfactory (57.14\%), and the overall mean of surgical results according to the need for new surgeries was $1.5 \pm 0.52$. Conclusion: cranioplasties of patients with extensive skullcap defects should obey careful and predetermined criteria, both for selection and for the acrylic implant customization method.
\end{abstract}

Keywords: Craniofacial Abnormalities. Acrylic Resins. Surgery, Plastic

\section{INTRODUCTION}

In the mid-1960s, Dr. Paul Tessier, the father of modern craniofacial surgery, revolutionized the surgical approach to craniofacial deformities by introducing new surgical concepts and techniques ${ }^{1}$. Since then, breakthroughs have been consistently established in the Craniofacial surgery field, and the principles founded by Dr. Tessier continue to be the standard in craniofacial care ${ }^{1}$. Among the innumerable principles described by him, there is the graft of the cranial bone for craniofacial reconstruction ${ }^{2}$. The mechanical, immunological and Techniques of autologous cranial grafts detailed in a series of seminal articles by Tessier et al. ${ }^{2,3}$ clearly state that this should be the standard material for craniofacial reconstructions, including in cranioplasties for congenital or acquired (oncological exertion, trauma or infection) skullcap defects.

Thus, the vast majority of patients have been reconstructed with autogenous tissues (particu- larly, bone grafts) in our and other centers ${ }^{3-8}$. However, the reconstructive approach of a portion of patients with extensive skullcap defects has been a major challenge for plastic surgeons working in the field of reconstructive surgery, as it often requires a large amount of tissue/material and complex surgical procedures soas to achieve the functional and aesthetic goals $\mathrm{s}^{9,10}$

In this particular group of patients, alloplastic implants may be a therapeutic option, although none of the described materials have the same success rate or predictability of the cranial autogenous bone ${ }^{3-11}$. Moreover, it is important to emphasize that even with proper planning and follow-up, the inclusion of any alloplastic material

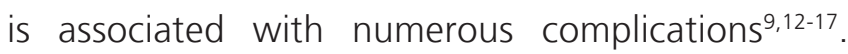
Therefore, considering the risks inherent to the use of alloplastic materials, such conduct should be considered as the exception approach in the scope of craniofacial reconstructions, and should be applied only in a restricted and well selected portion of patients ${ }^{9,12-17}$.

1 - SOBRAPAR Hospital, Institute of Craniofacial Plastic Surgery, Campinas, Sao Paulo State, Brazil. 
Therefore, the objective of the present study was to present the experience of a Brazilian craniofacial plastic surgery institution in the surgical reconstruction of extensive skullcap defects with customized acrylic implants, emphasizing that this should be an exception conduct, and highlighting the importance of patients' selection, as well as the risks associated with the use of alloplastic materials.

\section{METHODS}

This was a retrospective observational study of all patients with extensive skullcap defects treated surgically at the SOBRAPAR Hospital between January 2004 and March 2015. We included only patients submitted to cranioplasty with acrylic implants by the same group of plastic surgeons who were not lost topostoperative follow-up (minimum of 12 months). We collected demographic, clinical, and surgical data through medical records, photographs, cranial computed tomography (CT) with three-dimensional reconstruction (3D), 3D prototypes of the craniofacial skeleton (when available) and clinical consultations with all patients included.

The study was approved by the Ethics in Research Committee of the SOBRAPAR Hospital (002/15), and is in accordance with the Helsinki Declaration of 1975, perfected in 1983.

\section{Surgical approach}

In our center, only a particular and restricted group of carefully selected patients has been reconstructed with non-autogenous material. Thus, acrylic cranioplasty has been an exception course and is indicated only in patients with extensive skullcap defects (defined as defects greater than $25 \mathrm{~cm}^{2}$ ), 1820 , primarily to adequately protect the brain and secondarily to restore the curvature/craniofacial aesthetics. For this, we carefully assessed all patients with cranial bone defects through history (defect etiology, history of trauma, radiation and/or previous interventions) and physical examination (location and size of defects and quality of surrounding tissues). The soft parts (scalp) should provide adequate coverage for the implants; Portions of scar tissue ("thin and contracted tissues") were excised with or without tissue expansion. Incomplete craniofacial growth $^{21}$ and the presence of infection (active or recent), hydrocephalus, cerebral edema and/or allergy to acrylic components were contraindication criteria for such an approach.

\section{Customization of implants}

We customized the acrylic implants manually or with the help of a 3D biomodel prototype. The choice between the customization methods has been based on: a) the size of the defects ${ }^{8,18-20}$ (defects $>25 \mathrm{~cm}^{2}$ and $>200 \mathrm{~cm}^{2}$ have been preferably reconstructed with implants obtained manually and with the aid of 3D technology, respectively); and b) the preferences of the surgical team and of the patients/families, who received all the explanations about the differences and similarities of each method (detailed in the sequence).

\section{In-situ customization}

Initially, the powder (copolymer) and liquid (monomer) components were mixed at a ratio of approximately 2:1 with sterile vaseline. The mixture with a soft moldable consistency was poured over the defect of the skullcap and the implant was then cast in situ with a metal spatula, looking for an implant with smooth surface, adequate curvature and implantdefect fitting without movements. The process of implant hardening was accompanied by heat release (exothermic polymerization). In order to attenuate thermal effects to the surrounding tissues during polymerization, we take a few precautionary steps: 1) we carefully arranged a wet gelfoam interface and sterile glove (or sterile plastic bag) between the alloplastic and the bone collar and the underlying dura mater; 2) we continuously irrigated the alloplastic with cooled saline throughout the process. Once solid, the implant surfaces were carefully abraded it to mimic the contours of a normal skullcap.

\section{Prototyping-based customization}

The 3D biomodels used for implants customization were prototyped by the Renato Archer Center for Information Technology (CTI - http://www. cti.gov.br ${ }^{22}$. In summary, craniofacial tomographic 


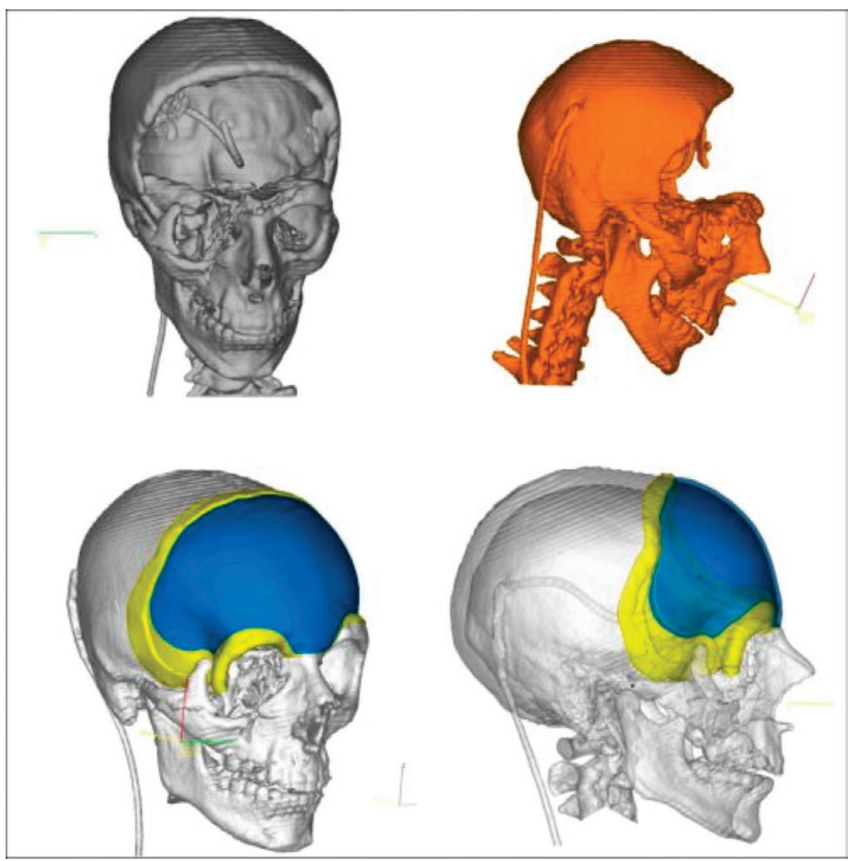

Figure 1. Craniofacial computed tomography with three-dimensional reconstruction: (Above) extensive skullcap defect and (Below) customized implant.

images in the DICOM format were processed with specific software (InVesalius and Rhinoceros) and transformed into Standard Triangulation Language (STL) format, creating the 3D virtual model of the craniofacial skeleton with the bone defect and the personalized implant (Figures 1 and 2). Subsequently, a physical replicate (3D biomodel of the craniofacial skeleton with the defect of the skullcap and the respective implant) was created with polyamide, by rapid prototyping. The 3D biomodel was then sent free of charge to our center.

We use the 3D biomodel as a positive mold to make a negative silicone rubber or alginate mold. The soft and moldable consistency blend (detailed above) was then poured into the negative mold. The positive mold was pressed onto the alloplastic to obtain the proper thickness. Finally, if necessary, we abraded the surfaces/edges to allow proper fitting of the implant in the 3D biomodel. Thus, we obtained an acrylic implant with exactly the same morphology as the positive template (prototyped implant). The implant was then sterilized in ethylene oxide. Recently, CTI has also shipped the custom acrylic implant. Thus, the donor implant is sterilized in ethylene oxide and used in the patient, without the need to be customized in our center.

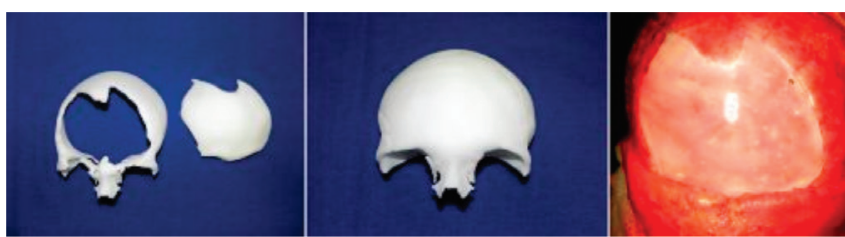

Figure 2. 3D Biomodel and implant fixed in the skullcap.

\section{Surgical interventions}

By means of coronal access (always distant from the cranial defect), subgaleal detachment and elevation of the periosteal flap, we carefully exposed the defect of the skullcap so as not to damage the dura mater. In the event of exposure / involvement of the frontal sinus, were performed cranialization, obliteration of the frontonasal duct and coverage with a pericranial flap. This was followed by the in-situ customization or fitting of the prototypebased implant. We then attached the implant to the bone margins with steel wires or metal screws. We proceeded with periosteal flap coverage, closure and tubular drainage. All patients received antibiotics for at least seven days and regular postoperative evaluation.

\section{Evaluation of surgical results}

A single plastic surgeon, who had no prior contact with the patients, evaluated the surgical results of the individuals who did not have the acrylic implants removed during the postoperative followup. For this, we used craniofacial photographs took by a professional photographer in a professional studio with three flashes. We classified preoperative and postoperative (12 months) photographs of all patients according to three previously published scales ${ }^{23-25}$. 1) Craniofacial aesthetics: excellent, good, regular or poor ${ }^{23}$. 2) Degree of improvement of craniofacial symmetry ${ }^{24}$ : satisfactory result, craniofacial symmetry; partially satisfactoryresult, global improvement of craniofacial symmetry, however craniofacial asymmetry can still be detected; or unsatisfactory result, absence of noticeable improvement of the craniofacial symmetry after the surgical interventions. 3) Need for additional cranial surgery ${ }^{25}$ : category I, does not require surgical revision; Category II, requires minor surgical revisions of the cranial contour; Category III, requires extensive surgeries (surgical 
Table 1. Distribution of patients ( $n=15)$ undergoing cranioplasties for reconstruction of skullcap defects.

\begin{tabular}{|c|c|c|c|c|c|c|c|c|c|c|}
\hline \multirow{2}{*}{$\begin{array}{l}\text { Acrylic custom } \\
\text { implants }\end{array}$} & \multirow{2}{*}{$\begin{array}{l}\text { Male/Female } \\
n(\%)\end{array}$} & \multirow{2}{*}{$\begin{array}{l}{ }^{*} \text { Age } \\
\text { (years) } \\
M \pm S D\end{array}$} & \multicolumn{3}{|c|}{$\begin{array}{c}\text { Cranioplasty Indication } \\
\mathrm{n}(\%)\end{array}$} & \multirow{2}{*}{$\begin{array}{l}\text { Seizure ** } \\
\text { (Yes/No) } \\
\mathrm{n}(\%)\end{array}$} & \multirow{2}{*}{$\begin{array}{c}\text { VPS } \\
\text { (Yes/No) } \\
n(\%)\end{array}$} & \multirow{2}{*}{$\begin{array}{c}\text { Local infection }^{* * *} \\
\text { (Yes/No) } \\
n(\%)\end{array}$} & \multirow{2}{*}{$\begin{array}{c}\text { Prior Cranioplasty } \\
\text { Attempt } \\
\text { (Yes/No) } \\
\mathrm{n}(\%)\end{array}$} & \multirow{2}{*}{$\begin{array}{l}\text { Size } \\
\text { of the } \\
\text { defects }\end{array}$} \\
\hline & & & Congenital & Tumor & Trauma & & & & & \\
\hline Manu & (85.71) & $26 \pm 12.29$ & $1(14.29)$ & $1(14.29)$ & $5(71.43)$ & $1(14.29$ & $-17(1$ & $1(14.2$ & $1(14.2$ & $>25$ \\
\hline$(n=8)$ & $7(87.5) / 1$ & $29 \pm 9.23$ & $2(25)$ & - & $6(75)$ & $3(37.5) / 5(62.5)$ & $2(25) / 6(62.5)$ & $-/ 8(100)$ & $1(12.5)$ & $>200$ \\
\hline Total & $\begin{array}{c}13(88.67) / 2 \\
(13.33)\end{array}$ & $.6 \pm 10.47$ & $3(20)$ & $1(6.67)$ & 11(73.33) & $4(33.33) / 11$ & $2(13.33) / 13$ & $1(6.67) / 14$ & $2(13.33) /$ & $>25$ \\
\hline
\end{tabular}

3D, three-dimensional; $n$, number of patients; Ventricle-peritoneal shunt VPS; *, at the time of the cranioplasties; **, all receiving anticonvulsant therapy; ***, previously treated (>6 months of first clinic visit in our Center); $¥$, cranioplasty with acrylic with unsatisfactory result 15 years before the cranioplasty held in our Centre (old acrylic removed intraoperatively); ¥¥, cranioplasty held with particulate bone that was reabsorbed (11 months before the cranioplasty held in our Center); -, missing.

intervention less than the main surgery); or Category IV, requires a complete new surgical intervention, similar to the main surgery.

All data was compiled in Excel for Windows (Microsoft Corporation, USA). For the descriptive analysis, we used the mean for metric variables and the percentages for categorical ones.

\section{RESULTS}

We included fifteen patients submitted to cranioplasties with acrylic implants (Table 1). All had cranial contour asymmetry. We performed 15 cranioplasties for the reconstruction of extensive skullcap defects (greater than $25 \mathrm{~cm}^{2}$ ), seven (46.67\%) with manually modified acrylic implants and eight (53.33\%) with prototyped 3D biomodels (Table 2). At an average follow-up of $7.89 \pm 2.47$ years (2.4 to 11$)$, there were no cerebrospinal fistulas, subcutaneous or extradural hematomas, implant migration, and/or new neurological deficits. In one (6.67\%) patient, there was a need to remove the implant after infection and in another $(6.67 \%)$ a postoperative seroma occurred (Table 2).

Excluding the patient (6.67\%) submitted to acrylic removal, we obtained an excellent craniofacial aesthetic appearance in seven (50\%) of the 14 remaining patients. The degree of craniofacial symmetry improvement was considered satisfactory (eight patients $-57.14 \%$ ) or partially satisfactory (six cases $-42.86 \%$ ) and the overall mean of the surgical results classified according to the need for new surgeries was $1.5 \pm 0.52$, between categories I and II (Figures 3 and 4 and Table 3). In this series, there

Table 2. Distribution of aspects related to the cranioplasties carried out for reconstruction of extensive skullcap defects ( $n=15)$.

\begin{tabular}{|c|c|c|c|c|c|c|c|c|c|c|c|c|c|}
\hline \multirow{2}{*}{$\begin{array}{l}\text { Acrylic } \\
\text { custom } \\
\text { implants }\end{array}$} & \multicolumn{7}{|c|}{$\begin{array}{l}\text { Anatomic location of cranioplasty } \\
\qquad n(\%)\end{array}$} & \multirow{2}{*}{$\begin{array}{c}\text { Surgical } \\
\text { Time } \\
(H) \\
M \pm S D\end{array}$} & \multirow{2}{*}{$\begin{array}{c}\text { Transfusion } \\
\text { (Yes/No) } \\
n(\%)\end{array}$} & \multirow{2}{*}{$\begin{array}{c}\text { Hospitalization } \\
\text { Time } \\
\text { (D) } \\
M \pm S D\end{array}$} & \multicolumn{2}{|c|}{$\begin{array}{c}\text { Postoperative } \\
\text { complications } \\
n(\%)\end{array}$} & \multirow{2}{*}{$\begin{array}{l}\text { Postop } \\
\text { Follow-up } \\
\text { (Y) } \\
M \pm S D\end{array}$} \\
\hline & Frontal* & $\begin{array}{c}\text { Frontal } \\
+ \\
\text { Occipital }\end{array}$ & $\begin{array}{c}\text { Right } \\
\text { Frontal** }\end{array}$ & $\begin{array}{c}\text { Right } \\
\text { Fronto- } \\
\text { parietal** }^{*}\end{array}$ & * $\begin{array}{c}\text { Left } \\
\text { Fronto- } \\
\text { parietala* }^{*}\end{array}$ & $\begin{array}{c}\text { Left } \\
\text { Fronto- } \\
\text { temporo- } \\
\text { parietal }\end{array}$ & Teft & & & & $\begin{array}{c}\text { Infection } \\
+ \\
\text { Implant } \\
\text { removed }\end{array}$ & Seroma & \\
\hline Manual $(n=7)$ & $3(42.86)$ & - & $1(14.29)$ & $1(14.29)$ & ) 1 (14.29) & - & $1(14.29)$ & $2.07 \pm 0.53$ & $1(14.29) / 6(85.71)$ & $1.57 \pm 0.53$ & - & $1(14.29)$ & $8 \pm 1.15$ \\
\hline $\begin{array}{l}\text { 3D Biomodel } \\
(n=8)\end{array}$ & $5(62.5)$ & $1(12.5)$ & $1(12.5)$ & - & - & $1(12.5)$ & - & $2.63 \pm 0.92$ & $1(12.5) / 7(87.5)$ & $2 \pm 0.76$ & $1(6.67)$ & - & $5.93 \pm 2.95$ \\
\hline Total $(n=15)$ & $8(53.33 \%)$ & $1(6.67)$ & $2(13.33)$ & $1(6.67)$ & $1(6.67)$ & $1(6.67)$ & $1(6.67)$ & $2.37 \pm 0.79$ & $2(13.33) / 13$ & $1.8 \pm 0.68$ & $1(6.67)$ & $1(6.67)$ & $6.89 \pm 2.47$ \\
\hline
\end{tabular}

$3 D$, three-dimensional; $H$, hour; $D$, days; $Y$, years; *, extensive commitment, with medial involvement; **, No medial commitment; -, absent. 
Table 3. Distribution of surgical results according to surgical interventions $(n=14)$.

\begin{tabular}{|c|c|c|c|}
\hline \multirow[b]{2}{*}{ Surgical results } & \multicolumn{2}{|c|}{ Acrylic custom implants } & \multirow{2}{*}{$\begin{array}{c}\text { Total }(n=14) \\
n(\%)\end{array}$} \\
\hline & $\begin{array}{c}\text { Manual }(n=7) \\
n(\%)\end{array}$ & $\begin{array}{c}\text { 3D Biomodel }(n=7) \\
n(\%)\end{array}$ & \\
\hline \multicolumn{4}{|l|}{ Craniofacial esthetic ${ }^{26}$} \\
\hline Excellent & $4(57.14)$ & $3(42.86)$ & $7(50)$ \\
\hline Good & $2(28.57)$ & $3(42.86)$ & $5(35.71)$ \\
\hline Regular & $1(14.29)$ & $1(14.29)$ & $2(14.29)$ \\
\hline Poor & - & - & - \\
\hline \multicolumn{4}{|c|}{ Improvement of craniofacial symmetry ${ }^{28}$} \\
\hline Satisfactory result & $4(57.14)$ & $4(57.14)$ & $8(57.14)$ \\
\hline Partially satisfactory result & $3(42.86)$ & $3(42.86)$ & $6(42.86)$ \\
\hline Unsatisfactory result & - & - & - \\
\hline \multicolumn{4}{|l|}{ Need for additional surgery ${ }^{29}$} \\
\hline Category I & $4(57.14)$ & $3(42.86)$ & $7(50)$ \\
\hline Category II & $3(42.86)$ & $4(57.14)$ & $7(50)$ \\
\hline Category III & - & - & - \\
\hline Category IV & - & - & - \\
\hline Total $(\mathrm{M} \pm \mathrm{Sd})$ & $1.43 \pm 0.53$ & $1.57 \pm 0.53$ & $1.5 \pm 0.52$ \\
\hline
\end{tabular}

n, number of patients; $M$, mean; SD, standard deviation; 3D, three-dimensional; *, one patient had the implant removed postoperatively (infection); -, absent.

was no poor, unsatisfactory result, category III and/ or category IV according to the previously published scales $23-25$.

\section{DISCUSSION}

Cranioplasty has been routinely applied in craniofacial plastic surgery centers to reverse the physiological status after craniectomies (trepanate syndrome), to protect brain structures and to improve the craniofacial contour of patients with defects in the skullcap.

In the literature, numerous factors (medical history, location and size of defects and reconstruction material) have been relevant in the scope of cranioplasties $9,10,17,19$. It is immense the variety of organic (autografts, allografts and xenografts), synthetic organic (hydroxyapatite) and inorganic (acrylic, silicone, porous polyethylene, titanium mesh, among others) ${ }^{11}$ materials that has been applied in the reconstruction of such defects $9,10,17$, with different success rates $4,7,9,10,12-17,19,20,23,26$.
By direct influence of Dr. Tessier, Prof. Dr. Cassio Menezes Raposo do Amaral (founder of the SOBRAPAR Hospital) established that the tissue substitutions based on autogenous tissues should guide the surgical treatments performed at our center. In addition, as members of a plastic surgery training center, the "replace like with like" principle of Dr. D. Ralph Millard Jr has been systematically passed on to all training residents. Thus, over the last 37 years, as defenders of these concepts, we have routinely reconstructed the skullcap bony defects with bone grafts obtained from the skullcap according to Dr. Tessier ${ }^{2,3}$. Other centers also support the reconstructive approaches of cranial defects with autogenous tissues, specifically obtained from the skullcap ${ }^{4,5,7,8}$.

Although the autogenous bone graft remains the gold standard for surgical reconstruction of most craniofacial bone defects $2,3-5,7-11$, a specific portion of patients, such as those included in the present study, have been reconstructed with alloplastics ${ }^{12-17,19,20,23,27}$. To date, there is no ideal alternative material $\left.\right|^{9,10,17}$ and there are characteristics that have been considered 


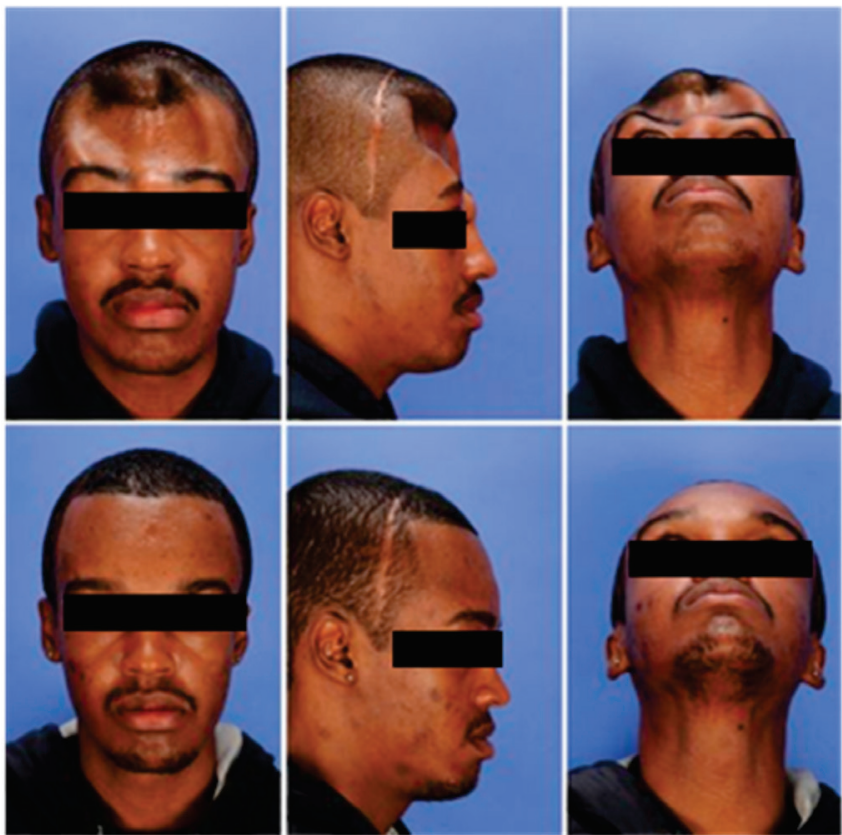

Figure 3. Before and after implant cranioplasty.

relevant in the choice of non-autogenous materials: 1) availability, 2) biocompatibility with surrounding tissue, 3) cranial contour, 4) easy molding, 5) sufficient strength to protect the intracranial content, 6) low likelihood of resorption, and 7) radiolucency (compatible with imaging tests)9,10,17. As acrylic implants are inert, easily available, inexpensive, radiolucent and resistant to absorption $9,10,13,20$, like other groups ${ }^{13,14,20}$, we prefer this material among the non-autogenous ones for reconstructions of extensive cranial defects, always respecting well-defined criteria for patient selection and follow-up.

Due to the lack of osseointegration, we and others ${ }^{9,10}$ believe that acrylic should not be used in patients without established skeletal growth, although there are experiments ${ }^{20}$ on the temporary use of acrylic based on the difficulty of bipartising the skullcap. However, this concept has recently been "demystified" 28 and cranial bony grafts can be obtained in children under three years of age.

In this context, different investigations ${ }^{9,12-17}$ have revealed numerous complications with this material. Infection has been the most commonly reported complication in acrylic cranioplasties, ranging from 3\% to $20 \%^{9,12-17}$. Numerous analyzes ${ }^{12,14-16}$ defined the factors associated with infections, including cranioplasty failure (implant removal), frontal and orbital defects with

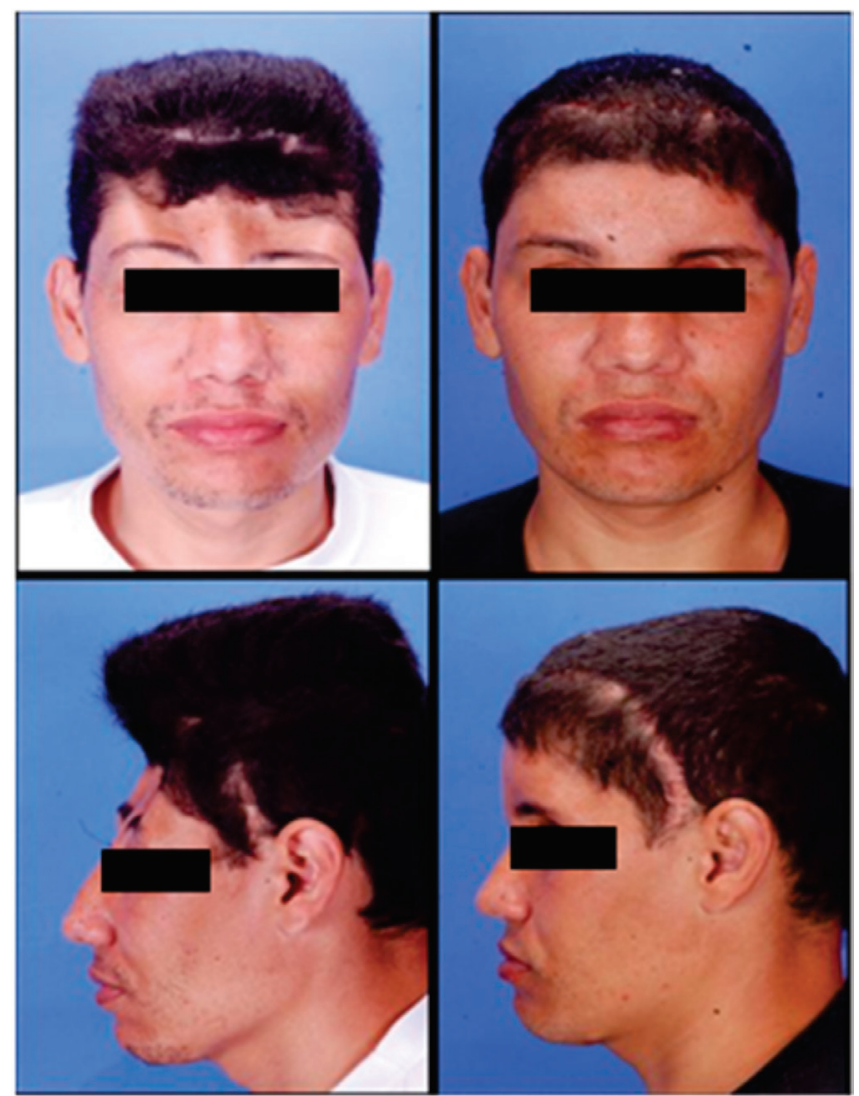

Figure 4. Before and after implant cranioplasty.

frontal sinus involvement, extensive brain resections and the presence of ventriculoperitoneal shunt. Therefore, all these factors should be carefully investigated in the preoperative period, allowing adequate selection and preparation of patients ${ }^{12,14-16}$.

However, although it is possible to achieve low infection rates in cranioplasties with acrylic implants as long as patients are carefully selected ${ }^{12,14-16}$, it is important to mention that since this material will never be integrated into the skullcap, there is a potential risk of infection and exposure at any time during the postoperative follow-up ${ }^{7}$. In addition, implants have been removed during infection, as described in our and other experiments ${ }^{7,14,20}$. Thus, patients with satisfactory results may present infection with extrusion, requiring implant removal, with complete loss of the obtained initiallyresult. Such risk, inherent in the use of alloplastics, should be carefully pondered in the preoperative period and the patient/family members should be adequately oriented regarding the risk of complications, even after a long postoperative period. 
Still within the scope of acrylic cranioplasties, the implants can be customized with or without the aid of prototyped 3D biomodels, as reported here. Cranioplasties with acrylic implants customized in situ have disadvantages, such as the need for intraoperative time to prepare the mixture, mold the implant and wait for hardening, as well as the risks of local thermal injury ${ }^{13}$.

Cranioplasties with prototyped acrylic implants have also been reported by different groups $^{14}$. It is undeniable that computer-aided design and computer-aided manufacturing (CADCAM) technology developed in recent decades has increased the armamentarium of the plastic surgeon who deals with complex defects and deformities of the craniofacial skeleton ${ }^{27}$. We have used the 3D biomodels prototyped by the CTI for the preoperative simulation and training of residents in the monobloc frontofacial advancement craniofacial surgeries and facial bipartition surgeries. We have also defined the accuracy of the reproducibility of craniofacial skeletal measurements in the 3D biomodels prototyped by the $\mathrm{CT}^{29}$. Such a method undoubtedly has multiple advantages, such as a shorter operative time related to the manipulation of the implant and the absence of local thermal effects ${ }^{13}$. However, cost increases as the technology is incorporated into the therapeutic process $^{13,27}$. Although the overall costs have been reduced with the $3 \mathrm{D}$ biomodel donation by $C T{ }^{29}$, there is a potential increase in time between the indication of cranioplasty and its realization, as delays can occur in the many stages of the 3D biomodel manufacturing process. For example, because the quality of prototy- ping is dependent on tomographic images with $1 \mathrm{~mm}$ slices and with good quality ${ }^{13,27}$, in the Brazilian Unified Health System (SUS) that has waiting queues for these tests and that lacks quality tomography scanners available in all services, it is not uncommon to find poor quality exams without adequate standardization and delays in performing and delivering CT scans.

In this series of carefully selected patients, we obtained an overall improvement of aesthetics and craniofacial symmetry with both methods of implant customization, following the trends reported by other groups $13,14,19,23$. In addition, our patients were classified, on average, between categories I and II and, therefore, required minor surgical revisions of the craniofacial contour, as previously reported ${ }^{14}$.

We must be careful about the influence that the industry has had on publications related to the technology used in bone substitutes, as pointed out by Rogers and Greene ${ }^{11}$. It is important to emphasize that the results obtained in the present study were limited to one restricted portion of carefully selected patients and therefore should not be extrapolated to other bone defects, in which reconstructions with the skullcap grafts remain the gold standard ${ }^{1-3,30}$.

In this retrospective study, we presented the surgical approach of patients with extensive cranial defects, based on our 11-year experience. According to the surgical results presented and discussed, the cranioplasties for these patients should be carefully indicated, obeying predetermined criteria for patient selection and customization of the acrylic implant.

\section{R E S U M O}

Objetivo: apresentar nossa experiência no tratamento cirúrgico dos defeitos extensos da calota craniana com implantes de acrílico customizados. Métodos: análise retrospectiva de pacientes com defeitos extensos da calota craniana submetidos à cranioplastias com acrílico entre 2004 e 2013. Todos os pacientes foram criteriosamente selecionados e os resultados cirúrgicos foram classificados com base em três escalas (estética craniofacial, melhora da simetria facial e necessidade de cirurgia adicional). Resultados: Quinze pacientes foram submetidos à cranioplastia com implantes de acrílico customizados manualmente no intraoperatório (46,67\%) e confeccionados com base em biomodelos tridimensionais prototipados (53,33\%). Mesmo respeitando critérios de seleção, houve duas (13,33\%) complicações (infecção com retirada do implante e seroma). A estética craniofacial foi considerada excelente (50\%), o grau de melhora da simetria craniofacial foi considerado satisfatório $(57,14 \%)$ e a média global dos resultados cirúrgicos de acordo com a necessidade de novas cirurgias foi 1,5 $\pm 0,52$. Conclusão: as cranioplastias dos pacientes com defeitos da calota craniana extensos devem ser criteriosamente indicadas, obedecendo a critérios pré-determinados de seleção dos pacientes, bem como, do método de customização do implante de acrílico.

Descritores: Anormalidades Craniofaciais. Polimetil Metacrilato. Cirurgia Plástica 


\section{REFERENCES}

1. Wolfe SA. Paul Tessier, creator of a new surgical specialty, is recipient of Jacobson Innovation Award. J Craniofac Surg. 2001;12(1):98-9.

2. Tessier P. Autogenous bone grafts taken from the calvarium for facial and cranial applications. Clin Plast Surg. 1982;9(4):531-8.

3. Tessier P, Kawamoto H, Posnick J, Raulo Y, Tulasne JF, Wolfe SA. Taking calvarial grafts, either split in situ or splitting of the parietal bone flap ex vivo-tools and techniques: V. A 9650-case experience in craniofacial and maxillofacial surgery. Plast Reconstr Surg. 2005;116(5 Suppl):54S-71S; discussion 92S-4S.

4. Lee HJ, Choi JW, Chung IW. Secondary skull reconstruction with autogenous split calvarial bone grafts versus nonautogenous materials. I Craniofac Surg. 2014;25(4):1337-40.

5. Chang TJ, Choi JW, Ra YS, Hong SH, Cho YH, Koh KS. Changes in graft thickness after skull defect reconstruction with autogenous split calvarial bone graft. J Craniofac Surg. 2014;25(4):1241-4.

6. Kumar AR, Tantawi D, Armonda R, Valerio I. Advanced cranial reconstruction using intracranial free flaps and cranial bone grafts: an algorithmic approach developed from the modern battlefield. Plast Reconstr Surg. 2012;130(5):1101-9.

7. Sahoo N, Roy ID, Desai AP, Gupta V. Comparative evaluation of autogenous calvarial bone graft and alloplastic materials for secondary reconstruction of cranial defects. J Craniofac Surg. 2010;21(1):79-82.

8. Zins JE, Langevin CJ, Nasir S. Controversies in skull reconstruction. J Craniofac Surg. 2010;21(6):1755-60.

9. Shah AM, Jung $H$, Skirboll S. Materials used in cranioplasty: a history and analysis. Neurosurg Focus. 2014;36(4):E19.

10. Goldstein JA, Paliga JT, Bartlett SP. Cranioplasty: indications and advances. Curr Opin Otolaryngol Head Neck Surg. 2013;21(4):400-9.

11. Rogers GF, Greene AK. Autogenous bone graft: basic science and clinical implications. J Craniofac Surg. 2012;23(1):323-7.

12. Reddy S, Khalifian S, Flores JM, Bellamy J, Manson PN, Rodriguez ED, Dorafshar AH. Clinical outcomes in cranioplasty: risk factors and choice of reconstructive material. Plast Reconstr Surg. 2014;133(4):864-73.

13. Jaberi J, Gambrell K, Tiwana P, Madden C, Finn $\mathrm{R}$. Long-term clinical outcome analysis of poly-methyl-methacrylate cranioplasty for large skull defects. J Oral Maxillofac Surg. 2013;71(2):e81-8.

14. Kumar AR, Bradley JP, Harshbarger R, Stevens F, Bell R, Moores L, Armonda R. Warfare-related craniectomy defect reconstruction: early success using custom alloplast implants. Plast Reconstr Surg. 2011;127(3):1279-87.

15. De Bonis P, Frassanito P, Mangiola A, Nucci CG, Anile C, Pompucci A. Cranial repair: how complicate disfilling a "hole"? J Neurotrauma. 2012;29(6):1071-6.

16. Gooch MR, Gin GE, Kenning TJ, German JW. Complications of cranioplasty following decompressive craniectomy: analysis of 62 cases. Neurosurg Focus. 2009;26(6):E9.

17. Neovius E, Engstrand T. Craniofacial reconstruction with bone and biomaterials: review over the last 11 years. J Plast Reconstr Aesthet Surg. 2010;63(10):1615-23.

18. Uygur S, Eryilmaz T, Cukurluoglu O, Ozmen S, Yavuzer R. Management of cranial bone defects: a reconstructive algorithm according to defect size. J Craniofac Surg. 2013;24(5):1606-9.

19. Marchac D, Greensmith A. Long-term experience with methylmethacrylate cranioplasty in craniofacial surgery. J Plast Reconstr Aesthet Surg. 2008;61(7):744-52; discussion 753.

20. Raposo-Amaral CE, Raposo-Amaral CA. Changing face of cleft care: specialized centers in developing countries. J Craniofac Surg. 2012;23(1):206-9.

21. Raposo-Amaral CE, Denadai R, Camargo DN, Artioli TO, Gelmini Y, Buzzo CL, et al. Parry-Romberg syndrome: severity of the deformity does not correlate with quality of life. Aesthetic Plast Surg. 2013;37(4):792-801.

22. da Silva JV, Martins TA, Noritomi PY. Scaffold informatics and biomimetic design: three-dimensional medical reconstruction. Methods Mol Biol. 2012;868:91-109.

23. Marbacher S, Andereggen L, Erhardt S, Fathi 
AR, Fandino J, Raabe A, Beck J. Intraoperative template-molded bone flap reconstruction for patient-specific cranioplasty. Neurosurg Rev. 2012;35(4):527-35; discussion 535.

24. Xie Y, Li Q, Zheng D, Lei H, Pu LL. Correction of hemifacial atrophy with autologous fat transplantation. Ann Plast Surg. 2007;59(6):645-53.

25. Denadai R, Raposo-Amaral CA, Marques FF, Ghizoni E, Buzzo CL, Raposo-Amaral CE. Strategies for the optimal individualized surgical management of craniofacial fibrous dysplasia. Ann Plast Surg. 2016;77(2):195-200.

26. Moreira-Gonzalez A, Jackson IT, Miyawaki T, Barakat K, DiNick V. Clinical outcome in cranioplasty: critical review in long-term follow-up. J Craniofac Surg. 2003;14(2):144-53.

27. Gerstle $T L$, Ibrahim AM, Kim PS, Lee BT, Lin SJ. A plastic surgery application in evolution: three-dimensional printing. Plast Reconstr Surg. 2014;133(2):446-51.

28. Vercler CJ, Sugg KB, Buchman SR. Split cranial bone grafting in children younger than 3 years old: debunking a surgical myth. Plast Reconstr Surg. 2014;133(6):822e-827e.

29. Almeida $A B$, Raposo-do-Amaral CE, Ferreira DM, Hotta L, Raposo-do-Amaral CA, Silva JVL, et al. Modelo tridimensional do esqueleto craniofacial: precisão de uma ferramenta para o planejamento cirúrgico. Rev Bras Cir Craniomaxilofac. 2009;12(1):5-9.

30. Wolfe SA. Frontal cranioplasty: risk factors and choice of cranial vault reconstructive material. Plast Reconstr Surg. 1986;77(6):901-4.

Received in: 16/10/2016

Accepted for publication: 18/12/2016

Conflict of interest: none.

Source of funding: none.

\section{Mailing address:}

Rafael Denadai Pigozzi da Silva

E-mail: denadai.rafael@hotmail.com rdenadaip@hotmail.com 